\title{
Crowdfunding - The Case of Slovakia and the Czech Republic
}

DOI: 10.12776/QIP.V20I2.807

\author{
Michal Šoltés, Tomáš Štofa
}

Received 10 August 2016, Revised 27 October, Accepted 21 November 2016

\begin{abstract}
Purpose: Crowdfunding as a form of alternative financing has become a widespread and successful form of financing new ideas. In this paper, we investigate crowdfunding in CEE countries, Slovakia and Czech Republic, with a strong focus on reward-based crowdfunding. The aim of this paper is to describe the current situation of crowdfunding in the Czech and Slovak Republic.
\end{abstract}

Methodology/Approach: We have analysed the Czech and Slovak market and compared it to the global platform Kickstarter in an attempt to find variables affecting the success of projects using linear and logistic regression.

Findings: The distribution of types of crowdfunding is similar to the global situation, but the low levels of awareness and conservatism are slowing down the speed of development of crowdfunding in Slovakia and the Czech Republic. We have also observed a higher degree of uncertainty and randomness in modelling of crowdfunding.

Research Limitation/implication: In this paper, not all crowdfunding portals have been included because of data unavailability.

Originality/Value of paper: The originality of this paper is guaranteed by its focus on the crowdfunding industry in the Czech and Slovak Republic.

Category: Research paper

Keywords: crowdfunding; reward-based; start-up; entrepreneurship; innovation 


\section{INTRODUCTION}

Crowdfunding became a financial phenomenon only a few years ago, but in a broader sense it has a long history. The main idea, collecting money from a crowd, is a form of charity used for centuries. Using crowdfunding as microfinancing dates back to the $18^{\text {th }}$ century, when Jonathan Swift started to give loans to low-income families. Other authors attribute the origin of crowdfunding to the subscription business model, where books were written and printed only in case of sufficient demand. All these ways of financing can be identified as forerunners of crowdfunding (Ordanini, et al., 2011).

We can talk about modern crowdfunding since the 20th century, when more individual projects were started with signs of crowdfunding. The emergence of new technologies and other aspects known as Globalization 3.0, significantly simplified the adoption of innovative financing (Szabo, Šoltés and Herman, 2013). According to Petrov (2015), the first successful crowdfunding project was created in 2003 by a web platform, ArtistShare. According to Statista (2016), the number of US crowdfunding platforms has risen six times during the period 2007-2011. Moreover, the crowdfunding volume has multiplied during this period. According to Massolution (2015), the worldwide crowdfunding volume doubled in 2015 , accounting for $\$ 34.4$ billion and it is going to exceed venture capital volume. Figure 1 shows the development of crowdfunding volume, where we can observe an exponential growth. It is worth mentioning the support provided by the government in USA and also in the most developed countries of the European Union by creating a legal framework and using financial injection in the last years.

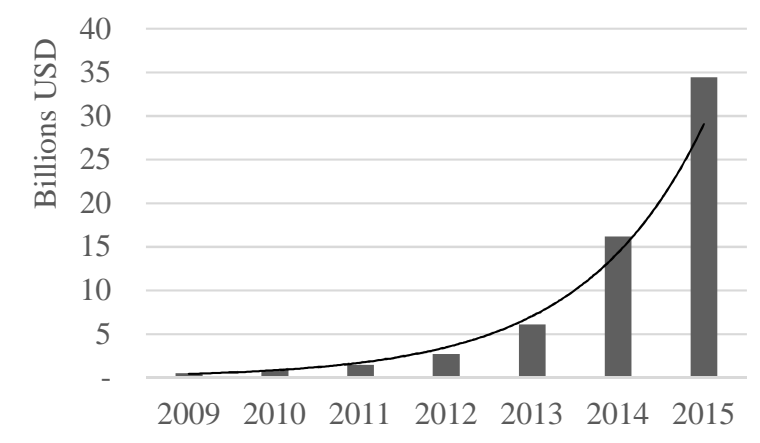

Figure 1 - Development of total crowdfunding volume in World Source: Massolution (2015)

Currently, there is a great development of innovative ideas. These ideas are the fruits of hard work of people, and obtaining money is usually a major challenge. Because of the risk, banks are not a good option for raising money, and therefore it is neccessary to find other alternative ways. Choosing a way of financing depends on the life cycle of the enterprise (Kádárová, Bajus and Rajnoha, 2015). 
Crowdfunding is one of the solutions to raise capital to support new projects or to set up a business. Compared to other financing alternatives, it offers various advantages and disadvantages, that may affect the choice of a financing method (Hudec, 2015; Mura and Buleca, 2012). Crowdfunding belongs to the group of alternative financing of a business, together with private equity or venture capital. Venture capital has a similar target group by supporting projects and companies in an early stage and with a high degree of risk. Venture capital is typical for interventions of investors in the management of the project. These interventions are consequences of the investor's effort to reduce project risk and to help it succeed by providing valuable information such as know-how and arranging contacts (Šoltés, V. and Šoltés, M., 2013).

\section{LITERATURE REVIEW}

First of all, we have to define the term crowdfunding. According to Schwienbacher and Larralde (2010), crowdfunding is "an open call, essentially through the Internet, for the provision of financial resources either in form of donation or in exchange for some form of reward and/or voting rights in order to support initiatives for specific purposes". Small contribution, a large number of contributors and the Internet are essential elements in the definition of crowdfunding. Small contributions are a sign of microfinance and crowd participation is the result of crowdsourcing (Mollick, 2013).

Crowdsourcing is the process of providing resources by a large number of people to carry out a specific role in product development. Using similar ideas included in this definitions, we can create a simple explanation of crowdfunding. It is a form of raising capital from a high number of individuals, to support startups or projects. Crowdfunding represents a new way of funding projects and enterprises, where a small contribution is provided from a high number of individuals almost exclusively via the Internet (Burtch, Ghose and Wattal, 2012). For a precise definition of the term it is necessary to emphasize the process of obtaining funds through the Internet platform, which is highlighted by Burtch, Ghose and Wattal (2012). Internet is seen as a tool for communication and campaign conduction. WEB 2.0 represents an important role in this definition. However, we can encounter the term Web 3.0, but as a new term it is not clear what it includes exactly (Bánciová and Raisová, 2012).

Portals bring together people looking to invest and people looking for investments. To protect the personal information of contributors and project developers, portals are used as a gateway and publish only necessary data. Donors may remain anonymous, but authors have to introduce themselves. According to Zheng, et al. (2014), contributors, applicants and portals are the basic types of actors connected by a crowdfunding portal. In a crowdfunding campaign, social networks are important and help to achieve a funding goal. Zheng, et al. (2014) have analyzed other dimensions of social capital, obligations and shared meaning, with positive effects on crowdfunding. Because of the 
specific development of China, they have found a stronger relation in China than in the USA.

According to Belleflamme, Lambert and Schwienbacher (2014), we can distinguish between four types of financing differing in forms of recompense, i.e. rewards-based, donor-based, equity-based and debt-based model. Crowdfunding platforms often focus on one type, but that does not exclude the offering of different crowdfunding types.

The first model, as the name suggests, takes the form of donations. Individual investors expect no reward for their contributions and so they can be described as philanthropists. This form is characteristic for cultural and social projects created mainly by non-profit and charitable organizations. Charity has a long history in Slovakia and it has been developing since 2007 in CEE countries (Belleflamme, Lambert and Schwienbacher, 2014).

The debt model represents the equivalent of borrowing. Contributors expect a certain amount of interest usually higher than in banks. A certain analogy is seen in P2P lending that meets several characteristics of crowdfunding. P2P lending is sometimes subdivided, but according to Massolution (2015), we will consider it a part of crowdfunding.

Equity crowdfunding is a little bit different, because it uses smaller numbers of investors and the fundig goals are much higher than in other types. Contributors usually gain a minor equity share in the business. Due to this fact, legalization and regulation were needed. It was performed through the Jumpstart Our Business Startups Act in the USA and via a directive Alternative Investment Fund Managers Directive in Europe. This directive has not created a fully integrated framework for equity crowdfunding throughout the European Union (Lasrado and Lugmayr, 2014).

The reward-based model is currently very popular around the world. Authors of the campaign get funds for their projects in exchange for a different reward, especially in the form of discounts on their products. This can be understood as a form of product pre-orders. Sponsors usually receive products earlier, but usually for a higher price than the final selling price. The smallest contributions get only small rewards, higher contributions are rewarded by more interesting products. (Belleflamme, Lambert and Schwienbacher, 2014)

The second subdivision represents projects with fixed or flexible funding. Projects with a fixed funding are the most common and also known as "all or nothing". The project is funded only if the funding goal is achieved. Pledges below the target amount mean failure of project and they are returned to the contributors. Flexible projects receive the amount collected, regardless of how much money was collected. Flexible projects are governed by the motto "keep it all" and they are used in donor-based models, but also in reward-based campaigns (Stroková and Bieliková, 2014). 
Fundraising is possible only during a campaign. A crowdfunding campaign usually lasts from 4 to 6 weeks, depending on portal policy or author selection. During this campaign the goal is to raise more money than the funding goal. At the beginning of a campaign, family and friends are the main sources of the collected money, but later the breaking point occurs and the project becomes viral (Belleflamme, Lambert and Schwienbacher, 2014).

Crowdfunding is a demand-oriented way of financing. The success of the campaign is the result of sufficient demand. Feedback is represented by comments and authors can use it for improving their ideas. Crowdfunding allows support to atypical projects with low chances of borrowing money from banks. Moreover, an unsuccessful campaign means that authors do not have to pay any fees. Pebble smart watch is an example of a successful crowdfunding campaign, in which, despite an unsuccessful venture capital financing, the funding goal was exceeded by 100-times (Mollick, 2013). On the other hand, projects are presented publicly, so the main idea of a project can be easily duplicated. The other negative aspect are the fees for a project. Usually, it is a certain percentage from the fundraised amount. To the negative aspects we can include the opportunity costs that are associated with venture capital, including contacts and know-how (Zheng et al., 2014).

\section{CROWDFUNDING IN SLOVAKIA AND THE CZECH REPUBLIC}

Slovakia and the Czech Republic are very similar countries with a shared history. They represent developing countries of the European Union with economies linked with each other. They have acted as independent countries since 1993, but a number of similar elements remained during their disaffiliation, for example similar constitution and laws. There is almost no language barrier, no law barrier, free movement of goods, capital, services, and people and therefore companies often act on both markets. Crowdfunding can be a good example of cooperation, since many portals operate in both Slovakia and the Czech Republic. Because of the interconnections of these countries we have decided to analyze the crowdfunding market for both countries.

Despite the small size of Slovakia and the Czech Republic, the crowdfunding market is growing very fast. Crowdfunding does not have direct regulation in these countries, but on the other hand legislation has general rules and restrictions for collecting funds from the public and their use, rules for the protection of consumers and prevention of money laundering. Regulation is performed by the following acts: Payment System Act, Banking Act, Consumer Protection Act, Civil Code, on Public Collections and Lotteries (Husták, 2015). The Czech Republic has also Act on Collective Investment and Act on Securities and Investment Services, in Slovakia there is the Act on Collective Investment. The recent amendment of these acts brought the legalization and regulation of all types of crowdfunding. 
In the case of Slovakia, crowdfunding occurred in 2007 already, in the form of a donor crowdfunding portal. Donor crowdfunding has the greatest experience in Slovakia, in the Czech Republic it is not so wide-spread and the first donor crowdfunding platform was founded only in 2016, but on the other hand other forms of charity have a long history. The Czech Republic has a more developed reward crowdfunding market. Reward-based projects have been provided by HitHit since 2011. In 2014, the biggest Czech reward crowdfunding portal HitHit entered the Slovak market. Since then, more portals have been created in Slovakia, but some of them have been already cancelled. The same situation can be observed on the Czech market. As an example, we mention four cancelled portals: Kreativcisobe.cz, Fondomat.cz, Ideasstarter.com and Odstartovano.cz. Equity crowdfunding has the smallest proportion with only 3 successful projects in Slovakia. This form is provided only by portal Crowdberry in Slovakia and the Czech Republic, but another platform Fundlift is entering the Czech market. Lending crowdfunding represented by $\mathrm{P} 2 \mathrm{P}$ lending is becoming quite popular. According to Massolution (2015), lending crowdfunding accounts for $72.99 \%$ of contributions in the world. In these countires, it is not so wide-spread and the first investments occurred in 2012.

\subsection{Methodology}

According to a number of journals in Web of Science, crowdfunding has become interesting for academics since 2012 and the number of papers is growing exponentially. The Slovak and Czech crowdfunding market is underdeveloped. In this paper, we provide an analysis of the market by investigating portals currently operating in these countries. After the market analysis, we discuss the reward crowdfunding model industry. We have found 18 operating portals on the Slovak and Czech market, but only 15 portals offered accessible data for analysis.

In this paper, we try to answer the following questions:

- What is the most wide-spread type of crowdfunding in the Czech and Slovak Republic?

- Are crowdfunding projects similar compared to the worldwide crowdfunding platform Kickstarter?

- Are there any patterns in crowdfunding campaigns?

- Are there any variables predicting the success of a project? Is their influence similar compared to other studies?

In the second part, we have collected 1036 reward crowdfunding projects from the Slovak and Czech portals. Data were unified for further analysis. It was necessary to solve the problem with different currencies. The Czech crown was converted to Euro using the current exchange rate $27.03 \mathrm{CZK} / \mathrm{EUR}$. Country assignment was not always available, but we have identified 66 Slovak and 713 Czech reward crowdfunding projects using the location of the project. 257 projects have not mentioned their location, or these projects were connected with 
other countries. For example, a planned expedition to Nepal had realization place Nepal, but it was realized by Czech authors. We have collected data from four portals: HitHit, Katalyzator, Marmelada and Startlab, because of unavailability of failed projects on other portals. HitHit platform is the most-represented portal with $92.13 \%$ of all Czechoslovak projects. Other sites included in the analysis were the Slovak sites Katalyzator, Marmelada and Startlab. The collected data are from the period November 2012 to January 2016 excluding ongoing campaigns. The number of projects ending in January was relatively small and this month was also excluded from the sample. Duration was a useless variable because of the fixed length of projects. In order to preserve the accuracy of the analysis, all projects with the "keep it all" idea were excluded too.

\subsection{Overview of Crowdfunding in Slovakia and the Czech Republic}

For a few years, crowdfunding in Slovakia and the Czech Republic collected $€ 10,592,844$. This sum was obtained by analyzing 15 portals. We have found few portals, that have already been cancelled, and therefore they were not analysed. Data from three other portals, two lending and one equity portal, were not available and so, they were excluded from the analysis too.

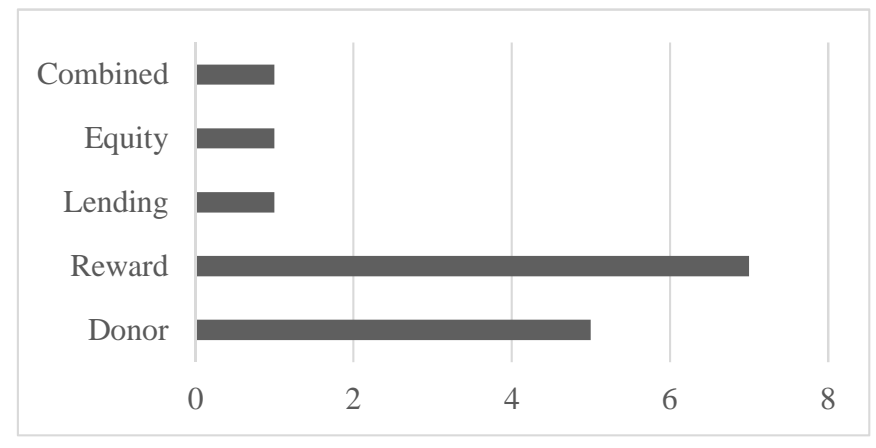

Figure 2 - Number of Czech and Slovak portals by category in 2016

A detailed crowdfunding analysis is presented in Fig.1 and Fig. 2. Fig. 1 shows the frequency of crowdfunding types in Czech and Slovak portals and Fig. 2 shows the amount of money collected on these portals. Data from two lending portals and from one equity portal were not available and therefore we did not include it in our exploration. Reward-based portals are the most numerous, but charity projects are available in other forms.

Donor crowdfunding P2P lending has the highest proportion of the collected amount, however, its proportion is only 37.09\% in the Czech Republic and Slovakia compared to $74.99 \%$ globally. The reason is mainly unavailable data for two portals Pujcmefirme.cz and Zinc Euro. Donor crowdfunding plays also an important role with $29.78 \%$ of market share, but $99.56 \%$ of pledges were from Slovak portals. Although, most sites provide reward crowdfunding, reward-based volume ranked only third place accounting for $24.88 \%$ of all pledges. Equity 
projects are relatively new for both markets and so their representation is very low. We have to mention that three successful projects collected EUR875,000, reaching $8.26 \%$ of market share. The last type was the combined model of reward and donor model, represented by platform Penězdroj. This portal is not as popular as others and recorded only very low turnover, EUR38,050 in total.

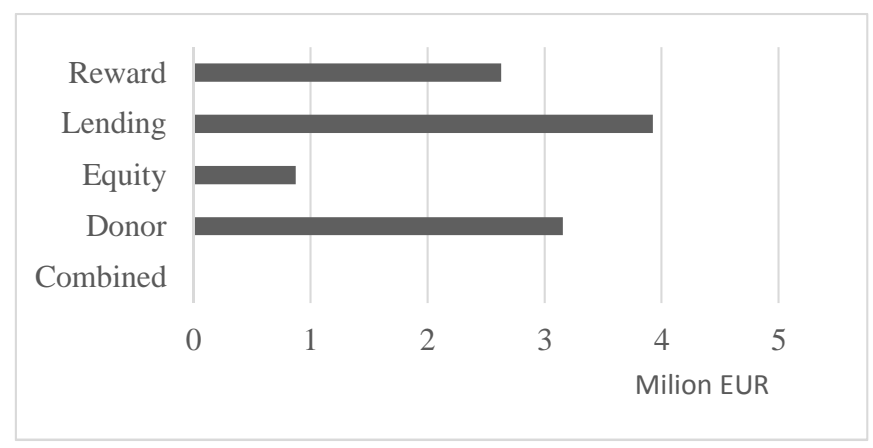

Figure 3 - Collected contributions of successful crowdfunding projects

\subsection{Comparing reward crowdfunding}

The most successful Czechoslovak crowdfunding portal is HitHit. Its biggest competitor Startovac.cz, however, does not disclose failed projects. Therefore, we included data only from four portals.

Table 1 -Reward-based crowdfunding portals in the Czech and Slovak Republic

\begin{tabular}{|c|c|c|}
\hline Portal & Origin & Particularities \\
\hline $\begin{array}{l}\text { HitHit } \\
\text { (Slovakia, Czech Republic) }\end{array}$ & $\begin{array}{l}2012 \text { in CZ, } \\
2014 \text { in SK }\end{array}$ & $\begin{array}{l}\text { Provision max } 9 \% \text { and bank fees } 1.5-2.5 \% \text {; } \\
\text { Fixed Duration of campaign, } 45 \text { days }\end{array}$ \\
\hline $\begin{array}{l}\text { Katalyzator } \\
\text { (Czech Republic) }\end{array}$ & 2014 & $\begin{array}{l}\text { Provision } 9 \% \text {; } \\
\text { Authors can set campaign duration }(30,45,60 \\
\text { days) }\end{array}$ \\
\hline $\begin{array}{l}\text { Marmelada } \\
\text { (Slovakia) }\end{array}$ & 2015 & $\begin{array}{l}\text { Provision } 8 \% \text { and bank fees } 1.59 \%+0.1 € \text { from } \\
\text { every contribution }\end{array}$ \\
\hline $\begin{array}{l}\text { Startlab } \\
\text { (Slovakia) }\end{array}$ & 2015 & $\begin{array}{l}\text { Provision } 6 \% ; \\
\text { „All or nothing“ and „Keep it all campaigns“, }\end{array}$ \\
\hline $\begin{array}{l}\text { Nakopni.me } \\
\text { (Czech Republic) }\end{array}$ & 2011 & Provision $3 \%$ \\
\hline $\begin{array}{l}\text { Startovac.cz } \\
\text { (Slovakia, Czech Republic) }\end{array}$ & 2013 & Provision 5-9\% \\
\hline $\begin{array}{l}\text { Everfund } \\
\text { (Czech Republic) }\end{array}$ & 2013 & $\begin{array}{l}\text { Provision } 8 \%+\text { bank fees } 1.4 \%-2.1 \%+1 \mathrm{CZK} \\
\text { from every contribution }\end{array}$ \\
\hline $\begin{array}{l}\text { Penezdroj } \\
\text { (Czech Republic) }\end{array}$ & 2015 & $\begin{array}{l}\text { Combination of donor, reward and equity } \\
\text { model; Provision Reward } 7 \% \text {, Dontaion } 3 \% \\
\text { and Equity } 7 \%\end{array}$ \\
\hline
\end{tabular}

Table 2 provides information about the success ratio of the projects in the analysed portals in comparison with Kickstarter. Data from Kickstarter were not 
used for total and average values. Kickstarter is not included in Total/Average values in any table.

Table 2 - Statistics of project success for the analysed portals

\begin{tabular}{|l|r|r|r|r|}
\hline Portal & Successful projects & Failed projects & Projects total & Success ratio \\
\hline Kickstarter & 106161 & 194350 & 300511 & $35.97 \%$ \\
\hline Hithit & 409 & 516 & 925 & $44.22 \%$ \\
\hline Katalyzator & 22 & 14 & 36 & $61.11 \%$ \\
\hline Marmelada & 8 & 17 & 25 & $32.00 \%$ \\
\hline Startlab & 14 & 4 & 18 & $77.78 \%$ \\
\hline Total /Average & 453 & 551 & 1004 & $45.12 \%$ \\
\hline
\end{tabular}

Comparing Kickstarter and the Slovak and Czech portals revealed a higher success ratio in the Czech and Slovak Republic. One of the possible answers is the low level of projects in these countries. Riskier projects are placed on worldwide sites like Kickstarter and Indiegogo to improve chances of success. We have found 20 Slovak and 122 Czech projects on Kickstarter's site and 38 Slovak and 76 Czech projects on Indiegogo. Startlab showed an above-average success ratio, but the reason was the availability of "keep it all" campaigns, allowing success of a campaign even though the goal has been not achieved.

Table 3 - Statistics of collected amount for analysed portals

\begin{tabular}{|l|r|r|r|r|r|}
\hline Portal & $\begin{array}{l}\text { Successful } \\
\text { projects }\end{array}$ & $\begin{array}{l}\text { Unsuccessful } \\
\text { projects }\end{array}$ & $\begin{array}{l}\text { Collected } \\
\text { total }\end{array}$ & $\begin{array}{l}\text { Average } \\
\text { Contribution }\end{array}$ & $\begin{array}{l}\text { Average } \\
\text { Percentage } \\
\text { funded }\end{array}$ \\
\hline Kickstarter & $2.116 b n \$$ & $0.282 b n \$$ & $2398 b n \$$ & $81.82 \$$ & $105 \% *$ \\
\hline Hithit & $1608770 €$ & $191712 €$ & $1800482 €$ & $30.02 €$ & $114.74 \%$ \\
\hline Katalyzator & $70058 €$ & $6728 €$ & $76787 €$ & $39.85 €$ & $119.18 \%$ \\
\hline Marmelada & $16279 €$ & $5272 €$ & $21551 €$ & $30.89 €$ & $104.89 \%$ \\
\hline Startlab & $62671 €$ & $1271 €$ & $63942 €$ & $28.47 €$ & $112.54 \%$ \\
\hline $\begin{array}{l}\text { Total } \\
\text { lAverage }\end{array}$ & $1757778 €$ & $204983 €$ & $1962762 €$ & $30.26 €$ & $114.73 \%$ \\
\hline
\end{tabular}

*According to Zheng and $\mathrm{Li}$

Comparing Kickstarter with the Slovak and Czech Crowdfunding Industry revealed that Slovak and Czech average contributions are much lower than the international ones. The average pledge on one person is $\$ 81.82$ considering only Kickstarter in USA, but only $€ 30.26$ in the Slovak and Czech market. This is confirmed by the Massolution report (2015), which claims that the European Crowdfunding Industry is developed only in the most advanced countries in the European Union, mainly United Kingdom and Germany.

\subsection{Distributions}

We have used histograms to compare the crowdfunding market in Slovakia and the Czech Republic. We can see differences between these markets, because the Czech reward crowdfunding market is more developed, but we have to 
emphasise the progress of the Slovak donor crowdfunding market. Our dataset contained 59 Slovak projects and 689 Czech projects. The remaining projects did not contain location information. We used public data about Kickstarter projects from CrowdBerkeley database (CrowdBerkeley, 2016).

By comparing campaign goals, we have found that the data samples do not come from the same distributions. To confirm this assumption, we have run the Kolmogorovov-Smirnovov test. The same test was used to compare the Czechoslovak market with USA projects. There are significant differences between samples. F-test and Student's t-test showed that the Czech projects have significantly higher average goal and standard deviation. By comparing the whole SK\&CZ crowdfunding industry with Kickstarter, we have confirmed again that samples do not come from the same distribution, and so we can draw the conclusion that there are significant differences between the Slovak and Czech market and between the international market too. Crowdfunding still has a long road ahead.
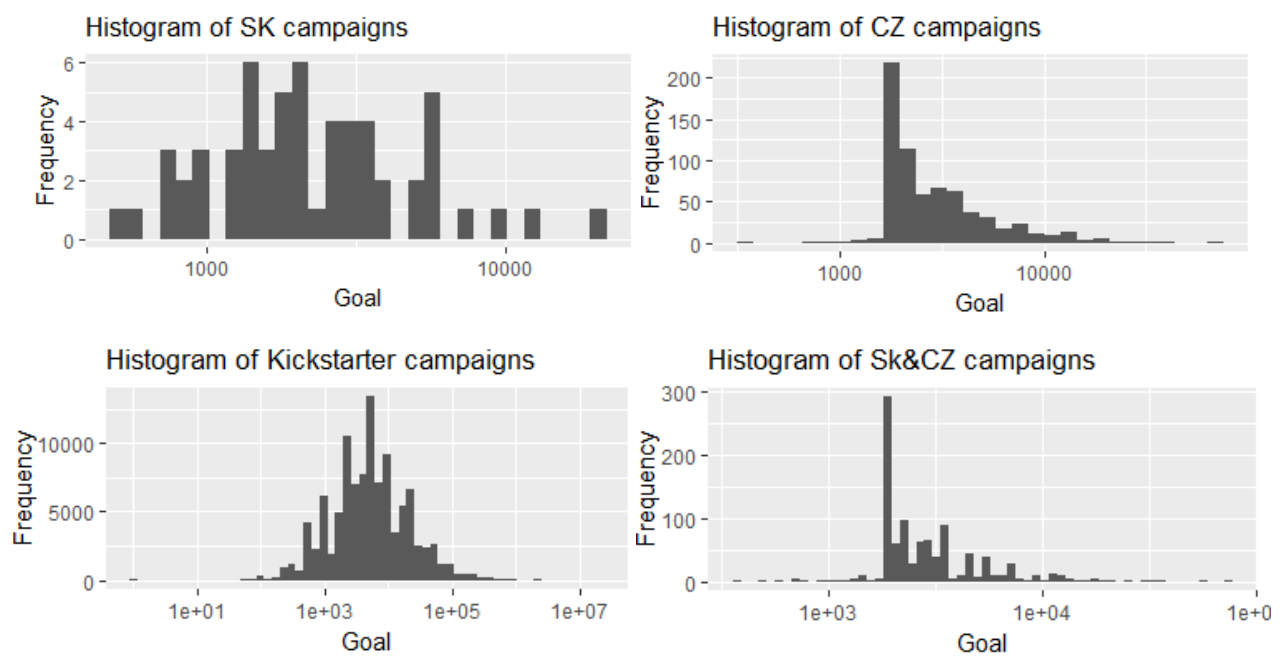

Figure 4 - Histograms of campaigns per data origin

Figure 5 shows distribution of projects according to the obtained ratio of percentage funded. Both distributions act like power laws, using certain bins. We had to limit the ratio of successful projects because of presence of extreme values. $25.22 \%$ of unsuccessful projects did not reach $1 \%$ of their goal. Only $50 \%$ of unsuccessful projects raised over $5.7 \%$ of their goal and only $2.5 \%$ of unsuccessful projects achieved $50 \%$ of their goal. On the other hand, $12.4 \%$ of the successful projects did not exceed the percentage funded of $101 \%$ and $61.6 \%$ did not exceed $110 \%$. $50 \%$ of the successful projects reached a lower success ratio, lower than 1.065 . Only $2.9 \%$ of successful projects scored over double of their goal. 

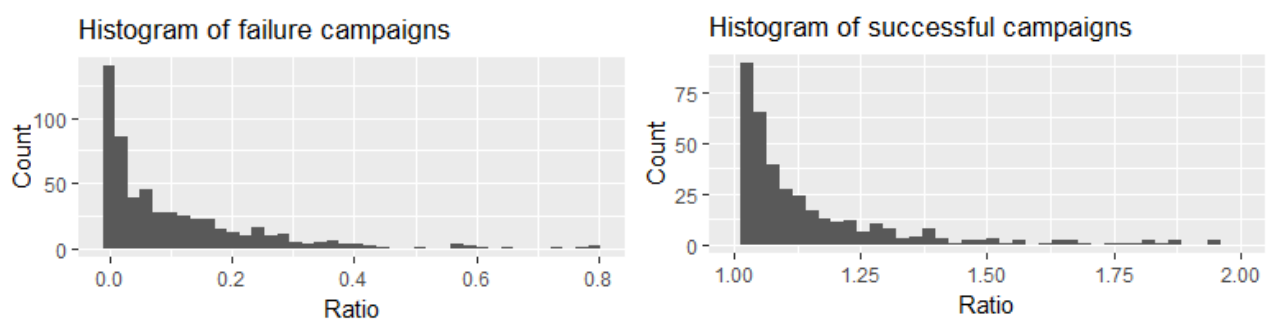

Figure 5 - Histogram of failure and successful campaigns based on ratio of percentage funded

\subsection{Data patterns}

The most successful project was project "Nakopni Jatka!", for the construction of a multifunctional theatre, reaching $121 \%$ of the CZK 2,000,000 goal. Project "SKINNERS - botky do kapsy" achieved the highest ratio funded, reaching $602 \%$ of their goal (CZK 542,051). This project brought compact foldable shoe. Successful projects achieved on average $116.24 \%$ of their goal. On the other hand, unsuccessful projects achieved only $10.35 \%$. The most common goal was set on CZK50,000, approximately EUR1,850, representing $22.78 \%$ of all goals.

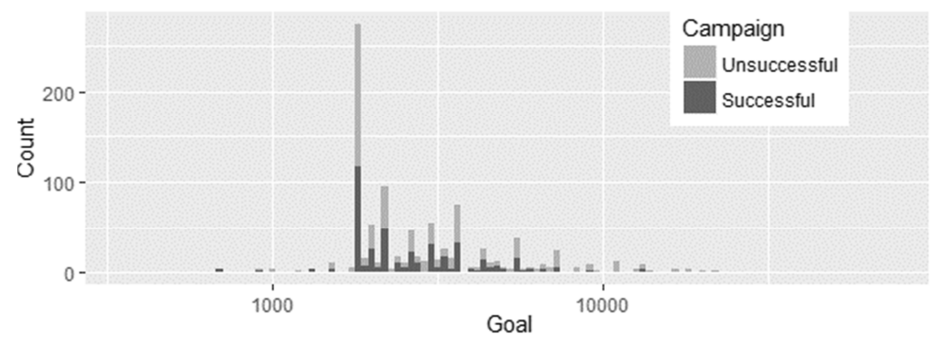

Figure 6-Histogram of campaigns based on goal using log scale

$87.9 \%$ of goals are distributed between $€ 1,300$ and $€ 7,000$. In Figure 7 , the development of a number of projects is shown. We can observe some signs of seasonality in crowdfunding. The beginning of the year is characterised by a decrease in project starts and we can observe some other signs in other months too (Štofa and Zoričák, 2016).

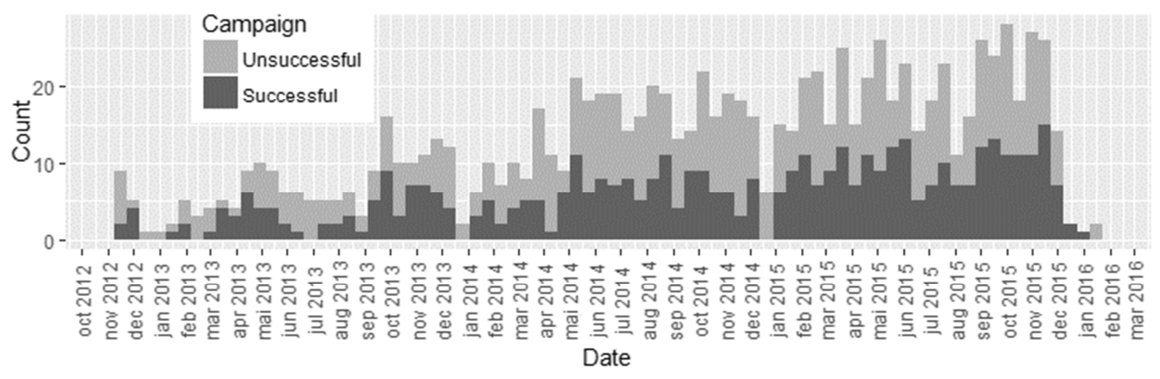

Figure 7 - Frequency of campaigns based on date 


\subsection{Reward-based crowdfunding models}

In order to analyse success factors, we have used the logistic and linear regression. In Table 4, we have the descriptive statistics of the studied data. The average contribution was calculated as donated amount divided by number of donors.

Table 4-Descriptive statistics of studied variables

\begin{tabular}{|l|r|r|r|r|}
\hline & \multicolumn{1}{|l|}{$\begin{array}{l}\text { Number of } \\
\text { Donors }\end{array}$} & $\begin{array}{l}\text { Donated } \\
\text { amount in EUR }\end{array}$ & Goal in EUR & Success ratio \\
\hline Average & 64.5 & 1922.7 & 3745.6 & $57.76 \%$ \\
\hline $\begin{array}{l}\text { Standard } \\
\text { deviation }\end{array}$ & 27.0 & 826.5 & 2441.0 & $26.99 \%$ \\
\hline Median & 147.9 & 4102.5 & 4452.7 & $58.87 \%$ \\
\hline Minimum & 0.0 & 0.0 & 370.0 & $0.00 \%$ \\
\hline Maximum & 3692.0 & 89554.0 & 73978.0 & $602.28 \%$ \\
\hline
\end{tabular}

The logistic model showed that only three important variables, i.e. goal, average pledge and number of donors are significant. Our model pointed out that projects with higher average pledge have a better chance for success, but its impact is very low. Furthermore, the number of donors had a positive impact. The most important variable was the logarithmic value of goal. We have found out that projects with higher goals have a lower chance for success. This finding is the same as the conclusions of other authors, hoverer, the impact of goal in this paper is much higher than in other papers. We see the reason for this in the lower willingness to donate to projects with a higher goal in the Czechoslovak market, because of a higher risk. The lower depth of market has an impact too. Other factors such as country, category, month and quarter of campaign start do not represent significant variables. Because country is a dummy variable, being a Slovak project reduces the log odds by 1.9521 compared with undetermined project, while a unit increase in $\log$ (goal) reduces the log odds by 7.8608 .

Table 5 - Results of logistic regression

\begin{tabular}{|l|r|r|r|}
\hline Variable & Estimate & Std. Error & Significance levels \\
\hline (Intercept $)$ & 51.155752 & 6.595193 & $\mathrm{p}<0.001$ \\
\hline $\log ($ goal $)$ & -7.799092 & 0.936485 & $\mathrm{p}<0.001$ \\
\hline donors & 0.146409 & 0.013826 & $\mathrm{p}<0.001$ \\
\hline average contribution & 0.082254 & 0.009955 & $\mathrm{p}<0.001$ \\
\hline factor(country)SK & -2.011582 & 0.883376 & $\mathrm{p}<0.01$ \\
\hline
\end{tabular}

The linear model has analyzed the factors influencing ratio pledge to goal. This ratio represents the achieved collected percentage of goal, therefore projects with a ratio higher than or equal to 1 represent successful projects. The most important factor was goal, negatively influencing percentage funded. We found also significant influence of February and June at Alpha level 99\%. They both have negative influence on percentage funded in comparison with January. Other 
months and categories did not show a significant impact. Logging of dependent variable was not possibile due to zero values of percentage funded.

Table 6 - Results of linear regression

\begin{tabular}{|l|r|r|r|}
\hline Variable & \multicolumn{1}{|l|}{ Estimate } & Std. Error & \multicolumn{2}{l|}{$\begin{array}{l}\text { Significance } \\
\text { levels }\end{array}$} \\
\hline (Intercept) & 2.7713066 & 0.2253193 & $\mathrm{p}<0.001$ \\
\hline $\log$ (goal) & -0.2955560 & 0.0274179 & $\mathrm{p}<0.001$ \\
\hline average contribution & 0.0032105 & 0.0003399 & $\mathrm{p}<0.001$ \\
\hline donors & 0.0020149 & 0.0001084 & $\mathrm{p}<0.001$ \\
\hline factor(month)2 & -0.2660861 & 0.0906706 & $\mathrm{p}<0.01$ \\
\hline factor(month)6 & -0.2752320 & 0.0852012 & $\mathrm{p}<0.01$ \\
\hline
\end{tabular}

The second model analyzed percentage funded as a dependent variable. In general, it showed similar results as the logistic regression with some particularities. Average pledge and number of donors had a significant impact, but their overall impact is low. Goal had also a negative impact on percentage funded as in the first model. Using not logarithmic values of goal we find that increasing goal by $€ 1$ decreases percentage funded by $0.006019 \%$. Variables category and country were not significant, but we found a new significant variable, campaign start month. February and June had a significant negative influence on the collected amount of money. Other months showed also a negative, but not significant effect in comparison to January. On $90 \%$ significance level, we observed a positive impact of category Impact Hub, but a negative impact of projects located in the Czech Republic. These categories were not included in our table.

\section{CONCLUSION}

Crowdfunding has become one of most important form of alternative financing. Because of gaining money for a specific purpose, it is experiencing great success. Despite the significant progress in the Slovak and Czech crowdfunding market, the reward crowdfunding industry is still popular only amnog a certain part of the population, especially early adopters and social-minded. In comparison with the highly developed crowdfunding market in the USA, Kickstarter, his effect in the Czech and Slovak Republic is lower and it has a long way ahead.

There are significant differences between countries, too. The reward model is very popular in the Czech Republic, and Czech portals are main drivers of growth of reward crowdfunding in Slovakia. We have observed also significant differences between distributions of goal and success ratio between countries. The Slovak Republic has a less developed crowdfunding industry. On the other hand, donor and lending models play a more important role in Slovakia. The equity model is new for both countries with only 3 successful projects so far.

On the other hand, reward-based crowdfunding campaigns modelling was more difficult. The most important variable was goal with a negative influence on 
success of campaign and also on percentage funded. We did not observe a significant impact of categorical variables such as category, country and origin portal. Seasonality assumption was confirmed only in percentage funded, but in general the impact was not significant. The relatively small sample could be also a source of these problems.

According to our results, we can give entrepreneurs some advice. When creating a campaign plan, they should be aware of setting their goals too high, because overestimating can lead to campaign failure. On the other hand, the goal should not be underestimated and authors should consider fees and other costs emerging in reward crowdfunding. Average contribution had a bigger impact than number of donors, and therefore we recommend to set slightly higher contributions compensated with more interesting rewards. Donors are ready to pay more money to get product in preference than in the classical way.

Our recommendation is to use more explanatory variables, according to other studies on social capital. Marketing could be another important factor, represented by video, pictures, shared content, number of rewards, and also promotion of project using social network websites and also crowdfunding platform.

\section{ACKNOWLEDGMENTS}

This research paper is made possible through the support from VEGA Project No. 1/0929/14 "Multidimensional economic and financial evaluation of the implementation process and the use of one day health care and quantification of the financial impact on the health care system in the Slovak Republic ".

\section{REFERENCES}

Bánciová, A. and Raisová, M., 2012. Issues of Slovak Business Environment. Procedia Economics and Finance, 3, pp.1223-1228.

Belleflamme, P., Lambert, T. and Schwienbacher, A., 2014. Crowdfunding: Tapping the right crowd. Journal of Business Venturing, 29(5), pp.585-609.

Burtch, G., Ghose, A. and Wattal, S., 2012. An Empirical Examination of the Antecedents and Consequences of Investment Patterns in Crowd-Funded Markets. Information Systems Research, Forthcoming. [online] Available at: https://papers.ssrn.com/sol3/papers.cfm?abstract_id=1928168 [Accessed 19 Nov. 2015].

CrowdBerkeley Database, 2016. Kickstarter Projects. [Public data > Kickstarter Projects]. [online] Available through: CrowdBerkeley

https://crowdfunding.haas.berkeley.edu/. 
Hudec, O., 2015. Visegrad Countries and Regions: Innovation Performance and Efficiency. Quality Innovation Prosperity, 19(2), pp.55-72.

Husták, Z., 2015. Crowdfunding - nové příležitosti a regulatorní implikace [Crowdfunding - new opportunities and regulatory implications]. Biatec, 23(5), pp.19-21.

Kádárová, J., Bajus, R. and Rajnoha, R., 2015. Optimal Financing of the Industrial Enterprise. Procedia Economics and Finance, 23, pp.953-958.

Lasrado, L.A. and Lugmayr, A., 2014. Equity crowdfunding - A finnish case study. In: 2014 IEEE International Conference on Multimedia and Expo Workshops (ICMEW). Chengdu, China, 14-18 July 2014. China.

Massolution, 2015. 2015CF Crowdfunding Industry Report. [pdf] Los Angeles: Massolution. Available at:

http://reports.crowdsourcing.org/index.php?route=product/product\&product_id= 54.

Mollick, E.R., 2013. The Dynamics of Crowdfunding: An Exploratory Study. Journal of Business Venturing, 29(1), pp.1-16. [online] Available at: http://www.sciencedirect.com/science/article/pii/S088390261300058X [Accessed 19 Nov. 2015].

Mura, L. and Buleca, J., 2012. Evaluation of Financing Possibilities of Small and Medium Industrial Enterprises. Procedia Economics and Finance, 3, pp.217-222.

Ordanini, A., Miceli, L., Pizzetti, M. and Parasuraman, A., 2011. Crowd-funding: transforming customers into investors through innovative service platforms. Journal of Service Management, 22(4), pp.443-470.

Petrov, A.P.I., 2015. Crowdfunding as an Alternative Source of Support for Entrepreneurial Initiatives. [online] Available at: http://jei.uni-ruse.bg/Issue2015/08.IvayloPetrov-

Crowdfunding\%20as\%20an\%20Alternative\%20Source\%20of\%20Support_web. pdf [Accessed 14 Apr. 2016].

Schwienbacher, A. and Larralde, B., 2010. Crowdfunding of Small Entrepreneurial Ventures. Handbook of Entrepreneurial Finance, Oxford University Press, Forthcoming. [online] Available at:

http://papers.ssrn.com/abstract=1699183 [Accessed 26 Nov. 2015].

Statista, 2016. Growth of number of crowdfunding platforms by category 2011 | Statistic. [Home > Industries > Finance, Insurance \& Real Estate > Banks \& Financial Services] [online] Available through: Statista http://www.statista.com/statistics/251577/growth-in-the-number-ofcrowdfunding-platforms-by-category/ [Accessed 14 Apr. 2016]. 
Stroková, Z. and Bieliková, T., 2014. Crowdfunding: nový trend vo financovaní [Crowdfunding: A New Trend in funding]. In: Trendy v podnikání. Mezinárodní vědecká konference Trendy v podnikání. Plzeň, 13-14 November 2014. Czech Republic.

Szabo, Z.K., Šoltés, M. and Herman, E., 2013. Innovative Capacity \& Performance of Transition Economies: Comparative Study at The Level of Enterprises. E $+M$ Ekonomie a Management/ E $+M$ Economics \& Management, 2013(1), pp.52-68.

Šoltés, V. and Šoltés, M., 2013. Rizikový a rozvojový kapitál v procese inovačného rozvoja [Venture capital in the process of innovation development]. In: Institute of Economic Research, Paradigmy budúcich zmien v 21. storočí : Európa, Slovensko - súvislosti globálneho ekonomického a mierového potenciálu. Smolenice, Slovak Republic, 16-18 September 2013. Bratislava: Ekonomický ústav SAV.

Štofa, T. and Zoričák, M., 2016. Selected Success Factors of Crowdfunding Projects. In: Proceedings of the 13th International Scientific Conference. [online] European Financial Systems 2016. Brno: Masaryk University. Available at: http://is.muni.cz/do/econ/sborniky/2016/EFS2016-

Proceedings_final_September_19_final.pdf.

Zheng, H., Li, D., Wu, J. and Xu, Y., 2014. The role of multidimensional social capital in crowdfunding: A comparative study in China and US. Information \& Management, 51(4), pp.488-496.

\section{ABOUT THE AUTHORS}

doc. Ing. Michal Šoltés, PhD. - Associate professor, Dean of Faculty of Economics, Technical University of Košice, Němcovej 32, 04001 Košice, Slovakia, e-mail: michal.soltes@ tuke.sk

Ing. Tomáš Štofa - Ph.D. Student at Technical University of Košice, Faculty of Economics, Němcovej 32, 04001 Košice, Slovakia, e-mail: tomas.stofa@tuke.sk 